\title{
Efficiency of calf production of cows from two genetic groups
}

\section{Luís Carlos Vinhas Ítavo ${ }^{1,5}$, Kepler Euclides Filho², Roberto Augusto de Almeida Torres Júnior², Camila Celeste Brandão Ferreira Ítavo ${ }^{3}$, Ériklis Nogueira ${ }^{4}$, Alexandre Menezes Dias ${ }^{3}$}

\author{
1 Universidade Catolica Dom Bosco, Campo Grande, MS, Brasil. \\ ${ }^{2}$ Empresa Brasileira de Pesquisa Agropecuária - Embrapa Gado de Corte, Campo Grande, MS, Brasil. \\ ${ }^{3}$ Universidade Federal de Mato Grosso do Sul, Campo Grande, MS, Brasil. \\ ${ }^{4}$ Empresa Brasileira de Pesquisa Agropecuária - Embrapa Pantanal, Corumbá, MS, Brasil. \\ ${ }^{5}$ Researcher CNPq
}

\begin{abstract}
The objective was to evaluate the effect of weight, age and production efficiency of cows from genetic groups based on the calf weight at calving and at weaning. For a period of five years, data of 120 cows (60 Angus-Nellore (AN) and 60 Simmental-Nellore (SN)) at four to nine-years of age were evaluated. All cows were maintained on Brachiaria decumbens pastures, with two forage availability levels (high and low), distributed in a randomized-block design. The cows were placed together with Canchim bulls to generate the crossbred calves. A supplement, consisting of $200 \mathrm{~g} / \mathrm{kg}$ crude protein and $820 \mathrm{~g} / \mathrm{kg}$ of total digestible nutrients, was provided to the calves in creep feeding until 210 days-old (weaning). Supplement had a significant effect on the weight of the cow at calving and weaning. The average weights of the Angus-Nellore cows were 529.19 and $514.23 \mathrm{~kg}$ at calving and on the weaning day, respectively. These values were higher for Simmental-Nellore cows, which presented 569.60 and $542.59 \mathrm{~kg}$, respectively. The male-calf weight at weaning was $254.69 \mathrm{~kg}$, which was higher than the females $(237.70 \mathrm{~kg})$. Genetic group had no effect on weaning weight. The average weight for Canchim $\times$ Angus-Nellore calves was $243.41 \mathrm{~kg}$ and for Canchim $\times$ Simmental-Nellore it was $248.98 \mathrm{~kg}$. Cow age affected weaning weight, promoting a linear increase of $0.804 \mathrm{~kg}$ in the weaning weight each year. Younger and smaller cows (Angus-Nellore) are more efficient for calf production.
\end{abstract}

Key Words: body size, calf performance, crossbreed, efficiency

\section{Introduction}

The choice of the system and crossbreeding type to be used depends on other segments of the meat-production chain. Morris and Wilton (1986), studying the economic aspects of various types and systems of crossbreeding, cow weight and milk yied on meat production, concluded that systems with high nutritional requirements are better when the price of meat was increased in relation to the price of the feed consumed. In tropical regions it would be difficult to obtain this favorable ratio, because the pasture is cheaper but presents inferior quality and seasonal production. Furthermore, the results obtained by Gregory (1972), Klosterman and Parker (1976), and Ferrel and Jenkins (1983) suggest that approximately half of the dietary energy expended in the process of beef production is used on the maintenance of cows, which generates an even more important concern with the body size and weight of the cow.

Received March 25, 2013 and accepted March 14, 2014.

Corresponding author: itavo@ucdb.br

http://dx.doi.org/10.1590/S1516-35982014000700008

Copyright $@ 2014$ Sociedade Brasileira de Zootecnia. This is an Open Access article distributed under the terms of the Creative Commons Attribution Non-Commercial License, which permits unrestricted non-commercial use, distribution, and reproduction in any medium, provided the original work is properly cited.
The adequacy of the cow genotype with the environment, mostly the quantity and quality of feed available, is a crucial element for the sustainability of the system. Larger pasture areas or lower stocking rates are required for large animals so that they can meet their nutritional requirements for maintenance and/or production; otherwise, according to Euclides Filho (1995), these will contribute to the degradation of pastures with consequent reduction in production rates.

Some experimental results indicate differences among genetic groups with regard to the efficiency of calf production. In Brazil, Euclides Filho et al. (1995) showed that Fleckvieh-Nellore cows were more efficient than Chianina-Nellore and Charolais-Nellore cows. The obtained rates were, respectively, $0.41,0.38$, and $0.38 \mathrm{~kg}$ of weaned calf $/ \mathrm{kg}$ of cow body weight.

The Brazilian cattle system has been going through various transformations which have been lately focused on increasing productivity, efficiency, and effectiveness of all sectors, especially the production system on farms. Euclides Filho (1996) analyzed the Brazilian cattle system and indicated that there would be an increase in the number of crossbred animals and a large participation of these animals in meat production. However, among other 
fundamental elements to be considered, the size of the cow and its milk production potential remain.

Jenkins and Ferrel (1994) observed that the efficiency of production of cows of different genetic groups was dependent on the dry matter intake. Although larger cows and/or cows with a high potential for milk production tend to produce larger calves at weaning and slaughter, they consume more food and have a higher maintenance requirement and may therefore not be the most efficient.

Thus, the objective was to evaluate the effect of the weight and age of cows of two genetic groups (AngusNellore or Simmental-Nellore) on the calf weaning weight on Brachiaria decumbens pastures, with two (high and low) forage availabilities.

\section{Material and Methods}

The experiment was carried out at the National Research Center for Beef Cattle (Empresa Brasileira de Pesquisa Agropecuária - Embrapa Gado de Corte), in Campo Grande, Mato Grosso do Sul State, Brazil.

Over a period of five years, data of 120 cows (60 Angus-Nellore (AN) and 60 Simmental-Nellore (SN)) between the ages of four and nine years-old were evaluated. Cows were kept on a pasture of Brachiaria decumbens, receiving mineral supplementation, with two forage availabilities (high and low amounts), in a randomizedblock design with two loads representing 80 and $120 \%$ of the requirements of each group.

The paddocks were initially formed after the soil preparation, which involved plowing and harrowing. To correct fertility, three tons of limestone/ha were distributed. A fertilizer with $400 \mathrm{~kg} / \mathrm{ha}$ superphosphate and $50 \mathrm{~kg}$ of micronutrients ( $\mathrm{Mo}, \mathrm{Cu}$, and $\mathrm{Zn}$ ) was prepared. Every year the 10-10-10 (N.P.K.) formula was scattered on the pastures.

Annually, during the reproduction period, all cows were placed together with Canchim bulls to generate the crossbred calves.
Ninety days after the start of partum period, troughs were placed with exclusive access for the calves (creep feeding), for the supply of concentrate feed. This supplement was composed of $715 \mathrm{~g} / \mathrm{kg}$ corn meal, $125 \mathrm{~g} / \mathrm{kg}$ soybean meal, $130 \mathrm{~g} / \mathrm{kg}$ cotton meal, $20 \mathrm{~g} / \mathrm{kg}$ molasses powder, and $15 \mathrm{~g} / \mathrm{kg}$ of a mineral mix with $200 \mathrm{~g} / \mathrm{kg}$ of crude protein and $820 \mathrm{~g} / \mathrm{kg}$ of total digestible nutrients on a dry matter basis.

The cows were weighed twice: at calving, and in June every year, when the calves were weaned. Calves were also weighted in June every year, when they weaned.

The experiment was established in a randomized-block design, in a $2 \times 2$ factorial arrangement consisting of two genetic groups (Angus-Nellore-AN and Simmental-Nellore$\mathrm{SN}$ ) and two forage availabilities on the paddock (80 and $120 \%$ of the requirements of each group). The statistical procedures were performed using the MIXED procedure of SAS software (Statistical Analysis System, version 9.2). The data were analyzed using the following model:

$$
\mathrm{Y}_{\mathrm{ijklm}}=\mu+\mathrm{GG}_{\mathrm{j}}+\mathrm{FB}_{\mathrm{k}}+\mathrm{GGFB}_{\mathrm{jkl}}+\mathrm{e}_{\mathrm{ijklm}},
$$

in which: $\mathrm{Y}_{\mathrm{ijklm}}=$ dependent variable; $\mu=$ overall mean; $\mathrm{GG}_{\mathrm{j}}=$ effect of genetic group $\mathrm{j}(\mathrm{j}=1$ - Angus-Nellore and 2 - Simmental-Nellore); $\mathrm{FB}_{\mathrm{k}}=$ effect of forage balance $\mathrm{k}$ $\left(\mathrm{k}=1\right.$ - high and 2 - low); $\mathrm{GGFB}_{\mathrm{jkl}}=$ effect of genetic group $\mathrm{j}$, with forage balances $\mathrm{k}$; $\mathrm{e}_{\mathrm{ijklm}}=$ random error, assumption $\operatorname{NID}(0, \sigma 2 \mathrm{e})$.

\section{Results}

Genetic group had a significant effect $(\mathrm{P}<0.001)$ on cow body weight at calving and weaning, with Angus-Nellore cows averaging 529.2 and $514.2 \mathrm{~kg}$, and SimmentalNellore cows averaging 569.6 and $542.6 \mathrm{~kg}$ for the weights at calving and weaning, respectively (Table 1).

The body weight (BW) of the cows at calving increased with age (Figure 1), and this increase was of approximately $19.2 \mathrm{~kg} / \mathrm{yr}(\mathrm{y}=412.11+19.211 \times$ cow age $)$. The age of the

Table 1 - Least squares means ( \pm standard error) of five years of cow body weight at calving (BWCoC) and weaning (BWCoW), calf (males and females) body weight at weaning $(\mathrm{BWCvW})$, and relationship between calf body weight at weaning and cow body weight at weaning (Weaning ratio)

\begin{tabular}{|c|c|c|c|c|c|}
\hline \multirow{4}{*}{ Variable } & \multicolumn{4}{|c|}{ Cow genetic group ${ }^{1}$} & \multirow{4}{*}{ P-value } \\
\hline & \multicolumn{2}{|c|}{ Angus-Nellore } & \multicolumn{2}{|c|}{ Simmental-Nellore } & \\
\hline & \multicolumn{4}{|c|}{ Forage availability } & \\
\hline & High & Low & High & Low & \\
\hline BWCoC (kg) & $532.98 \pm 11.29 b$ & $525.41 \pm 12.87 \mathrm{~b}$ & $565.07 \pm 16.97 \mathrm{a}$ & $574.14 \pm 11.65 \mathrm{a}$ & $<0.001$ \\
\hline BWCoW (kg) & $521.41 \pm 11.78 \mathrm{c}$ & $507.05 \pm 12.75 d$ & $532.19 \pm 15.66 b$ & $553.00 \pm 11.27 \mathrm{a}$ & $<0.001$ \\
\hline BWCvW (kg) & $247.74 \pm 5.63 \mathrm{a}$ & $239.08 \pm 5.45 b$ & $248.16 \pm 7.31 \mathrm{a}$ & $249.81 \pm 5.01 \mathrm{a}$ & $<0.001$ \\
\hline Weaning ratio & $0.4864 \pm 0.02 \mathrm{a}$ & $0.4783 \pm 0.02 b$ & $0.4804 \pm 0.02 \mathrm{a}$ & $0.4576 \pm 0.01 \mathrm{~b}$ & $<0.001$ \\
\hline
\end{tabular}

${ }^{1}$ Means followed by different lowercase letters in the same row differ by Tukey's test $(\mathrm{P}<0.001)$. 
cow had a positive influence on the cow weaning weight (Figure 2), resulting in a weight increase of $19.98 \mathrm{~kg} / \mathrm{yr}$ $(y=405.78+19.984 \times$ cow age $)$.

Depending on the sex of the calf there is a significant difference in the weight of the calves at weaning. The males presented an average weaning weight of $254.69 \mathrm{~kg}$, which was higher $(\mathrm{P}<0.001)$ than the females $(237.70 \mathrm{~kg})$.

There was no effect on the calf body weight, for the two genetic groups at weaning. The medium-sized calves (Canchim $\times$ Angus-Nellore) presented $243.41 \mathrm{~kg}$ and the weaning weight of large calves (Canchim $\times$ SimmentalNellore) was $248.98 \mathrm{~kg}$. In a pooled analysis, the forage availability did not influence the weight at weaning. The average weight at weaning for the high availability was $247.9 \mathrm{~kg}$, and for the low availability it was $244.4 \mathrm{~kg}$.

Cow age affected $(\mathrm{P}<0.001)$ the weight at weaning, with a linear increase in the calf weight of $0.804 \mathrm{~kg} / \mathrm{yr}$ of cow age (Figure 3). The adjusted model was positive and linear as a function of cow age $(y=239.54+0.80 \times$ cow age $)$.

There was a significant effect on weaning ratio (Calf weight:Cow weight at weaning). The adjusted model was exponential $(\mathrm{y}=0.5459-0.0117 \times$ cow age $)$, decreasing as cow age increased. In short, as the cow grows older, there is a reduction of $-0.0117 \mathrm{~kg}$ every year (Figure 4 ).

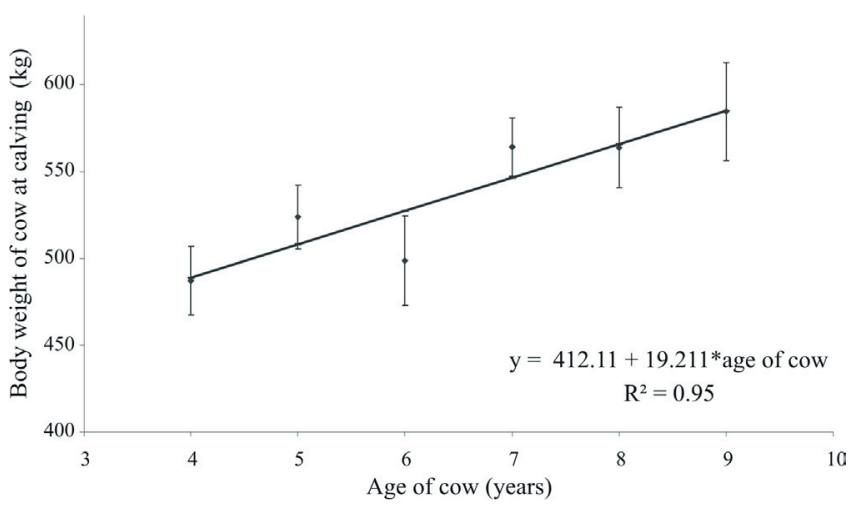

Figure 1 - Cow body weight at calving as a function of its age in years.

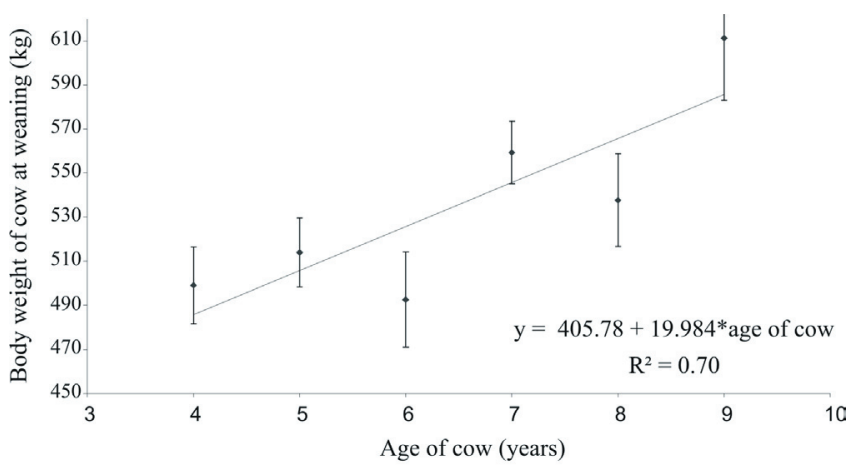

Figure 2 - Cow body weight at weaning as a function of its age in years.
Genetic group and forage availability affected $(\mathrm{P}<0.001)$ the calf weight:cow weight at weaning ratio (Table 1). The calf weight:cow weight at weaning ratio averages of high and of low forage availability were, respectively, $0.486 \mathrm{vs}$. 0.478 for Angus-Nellore, and 0.480 vs. 0.457 for SimmetalNellore.

The sex of the calves had a significant effect $(\mathrm{P}<0.001)$ with an average of 0.497 for males and 0.454 for females. The average calf weight:cow weight at weaning ratio was 0.482 for Angus-Nellore and 0.469 for Simmetal-Nellore animals $(\mathrm{P}=0.0694)$.

\section{Discussion}

Performances of cows and calves weaned at 90 (D90) and 210 days of age (D210) were evaluated by Ítavo et al (2007), using 36 Beefalo-Nellore multiparous cows and their calves. The average weaned body weight of calves on Brachiaria decumbens pasture was $208.68 \mathrm{~kg}$ for 210-day calving with supplementation (creep feeding). Cows from the 90-day calving treatment showed higher body weight $(448.86 \mathrm{~kg})$ at 210 days postpartum.

The weight from calving to weaning in both cow groups showed a reduction (Table 1). This fact suggests that

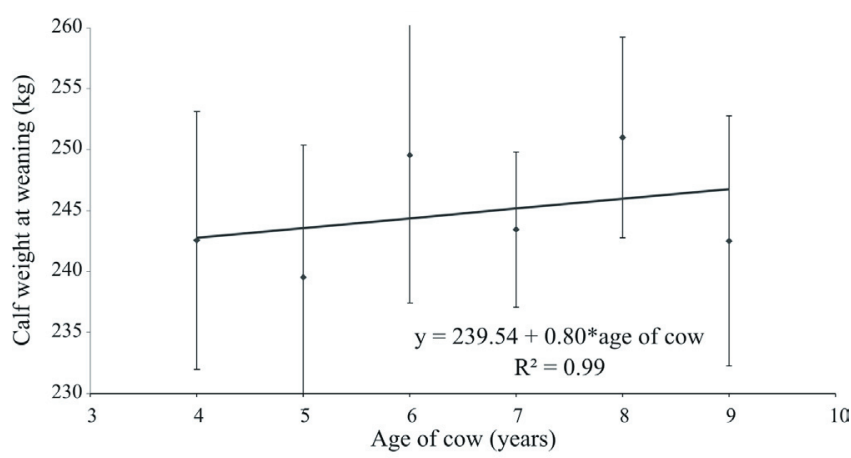

Figure 3 - Calf body weight at weaning as a function of cow age at calving.

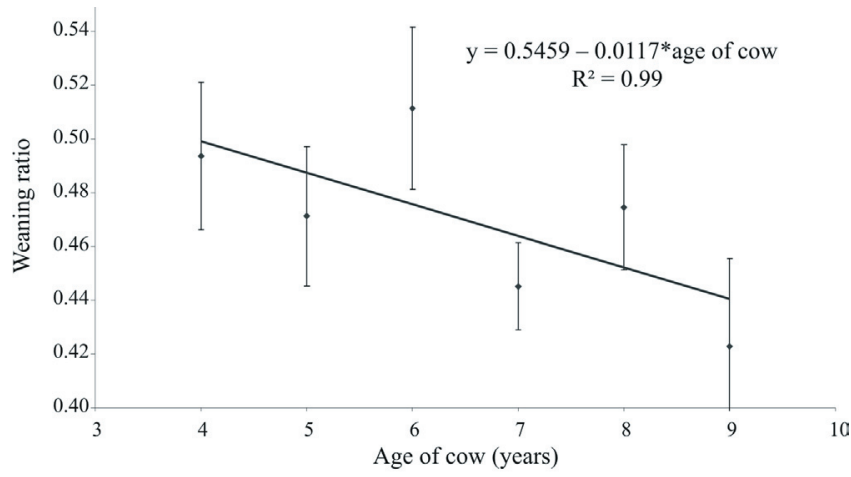

Figure 4 - Relationship between calf body weight at weaning and cow body weight at weaning. 
cows had a large production of milk during lactation even when calves received exclusive supplementation - creep feeding. This caused an increased demand for nutrients that was probably not entirely met by grazing Brachiaria decumbens in either high or low availabilities. However, because the supplementation was 90 days overdue after calving, this may be one of the factors that slowed down the rumen development.

Creep-feeding was suggested for weaning heavier calves. Probably because of genetic differences, these results are lower than those presented for cow weight and the weight of calves at weaning (Table 1). However, the body weight of Angus-Nellore cows is similar to that of Beefalo-Nellore, but their milk production is probably different.

According to NRC (2001), cows often weight loss, during early lactation, when fed in limited quantities and the feed quality is low. And weight gain is higher when the forage quality is more abundant or if the nutrient demand of the cow is smaller. It was observed that the weight of the cows at calving and weaning was influenced by the forage availability $(\mathrm{P}=0.001)$, with an overall average of 549.4 and $528.4 \mathrm{~kg}$, respectively (Table 1).

The body weight (BW) of the cows at calving increased by $19.2 \mathrm{~kg}$ per year and the cow age had a positive influence on its weaning weight (Figure 2). Euclides Filho et al. (1983), evaluating Brown-Swiss, Angus, and Angus $\times$ Brown-Swiss F1 cows, showed that crossbreed cows of higher milk yield and larger (Angus $\times$ Brown-Swiss F1), produced heavier calves at weaning. Thus, the maintenance of older cows in the production system generates a necessity to increase the availability of feed. Because animals are heavier and larger in size, there is a need for greater nutrient intake, as opposed to smaller animals (NRC, 2001).

According to Szabó et al. (2006), the contribution to the total phenotypic variance of the 205-day weaning weight was: $18.60 \%$ by breed, $2.79 \%$ by age of dam, $43.23 \%$ by birth year, $3.95 \%$ by birth season, and $31.43 \%$ by sex of calf. These reports are consistent with the results presented in Figure 3. However, when the amount of food ingested by the mother-calf pair and the birth rate were evaluated, results showed that the Angus cows were more efficient.

The calf body weight values can be considered high because all calves receive exclusive supplementation (creep feeding), providing increments in weaning weight. Different results were observed by Euclides Filho et al. (1983), showing that the higher milk production and greater size of the cow resulted in greater weight at weaning for their calves.

The effect of cow age $(\mathrm{P}<0.001)$ on the weight at weaning suggests that older cows are more suitable for the production of heavier calves (Figure 3).
The significant effect on weaning ratio (calf weight: cow weight at weaning) could be linked to the use of animals with a high potential for weight gain and the use of supplementation during the growth phase, since calving. These would be factors to be considered in the production systems in terms of finishing young cattle.

Perotto et al. (2001) studied weaning weight in sevenmonth-old Charolais and Caracu breeds and their crosses, and observed that the average weaning weight was $165.0 \mathrm{~kg}$. This weight is lower than those obtained for both genetic groups evaluated herein. However, the calves in the above mentioned experiment were not supplemented.

Szabó et al. (2006) evaluated weaning weights of 442 beef calves (223 male and 219 female) born between 1997 and 2004 from cows of nine breeds (Hungarian Fleckvieh, Hereford, Aberdeen Angus, Red Angus, Lincoln Red, Charolais, Limousin, Blonde d'Aquitaine, and Shaver) and maintained in the same conditions on peat-bog soil pasture at Keszthely. The average 205-day weaning weight of all calves was $193 \mathrm{~kg}$, with male calves reaching $202 \mathrm{~kg}$ and female calves $185 \mathrm{~kg}$ of the adjusted weaning weight. These results were lower than the average weaning weight $(238.93 \mathrm{~kg})$ obtained in a pooled analysis with overall calves.

According to Szabó et al. (2006) there was effect of dam age, wherein the weaning weight increased up to 5 years and decreased after its maximum $(205 \mathrm{~kg})$. This fact was also true for both Angus-Nellore and SimmentalNellore cow groups.

The calf weight:cow weight at weaning ratio (Table 1) results indicate that an increase in forage availability is necessary for larger cows, such as Simmental-Nellore. This could result in cows producing heavier calves at weaning, which would be compatible to the size of the cow.

\section{Conclusions}

The age of cows can affect the calf weaning weight. Younger and smaller (Angus-Nellore) cows are more efficient at weaning with regard to the calf weight:cow weight at weaning ratio.

The low forage availability can negatively influence calf weaning weight on Brachiaria decumbens pastures.

\section{References}

Euclides Filho, K. 1995. Melhoramento animal: conquistas e perspectivas. p.611-615. In: Anais da 32a Reunião Anual da Sociedade Brasileira de Zootecnia. Sociedade Brasileira de Zootecnia, Brasília.

Euclides Filho, K. 1996. A pecuária de corte brasileira no terceiro milênio. p.118-120. In: Anais do 8 - Simpósio sobre o Cerrado; 
1ํ International Symposium on Tropical Savannas, Brasília. Biodiversidade e produção sustentável de alimentos e fibras nos cerrados. EMBRAPA-CPAC, Planaltina.

Euclides Filho, K.; Figueiredo, G. R. and Euclides, V. P. B. 1995. Eficiência de produção de vacas de corte com diferentes potenciais para produção de leite. Pesquisa Agropecuária Brasileira 30:1003-1007.

Euclides Filho, K.; Restle, J.; Olson, T. A; Koger, M. and Hargrove, D. D. 1983. Measures of efficiency of calf production from cows of different sizes and milking abilities. Florida Beef Cattle Research Report, p.13-17.

Ferrel, C. L. and Jenkins, T. G. 1983. Estimated production efficiencies of crossbred cows. Journal of Animal Science 57(suppl. 1):154.

Gregory, K. E. 1972. Beef cattle type for maximum efficiency "Putting it all together". Journal of Animal Science 34:881-884.

Ítavo, L. C. V.; Ítavo, C. C. B. F.; Souza, S. R. M. B. O.; Dias, A. M.; Coelho, E. M.; Morais, M. G. and Silva, F. F. 2007. Avaliação da produção de bezerros em confinamento ou em suplementação exclusiva. Arquivo Brasileiro de Medicina Veterinária e Zootecnia 59:948-954.

Jenkins, T. G. and Ferrel, C. L. 1994. Productivity through weaning of nine breeds of cattle under varying feed availabilities: I. Initial evaluation. Journal of Animal Science 72:2787-2797.

Klosterman, E. W. and Parker, C. F. 1976. Effect of size, breed and sex upon feed efficiency in beef cattle. Research Bulletin. Ohio Agricultural Research and Development Center, Columbus, Ohio.

Morris, C. A. and Wilton, J. W. 1986. Breeding system, cow weight and milk yield effects on various biological variables in beef production. Journal of Animal Science 63:1361-1372.

NRC - National Research Council. 2001. Nutrients requirements of beef cattle. 7th ed. National Academy Press, Washington, D.C.

Perotto, D.; Abrahão, J. J. S. and Kroetz, I. A. 2001. Produtividade à desmama de novilhas Nelore e F1 Bos taurus x Nelore e Bos indicus x Nelore. Revista Brasileira de Zootecnia 30:1712-1719.

Szabó, F.; Nagy, L.; Dákay, I.; Márton, D.; Torok, M. and Bene, S. Z. 2006. Effects of breed, age of dam, birth year, birth season and sex on weaning weight of beef calves. Livestock Science 103:181-185. 